\title{
The Customer Satisfaction Analysis of Community based Agrotourism in Yogyakarta
}

\author{
Temy Indrayanti ${ }^{1,2 *}$, Jamhari ${ }^{3}$, Jangkung Handoyo Mulyo $^{3}$ and Masyhuri ${ }^{3}$ \\ ${ }^{1}$ Department of Agricultural Science, Faculty of Agriculture, Universitas Gadjah Mada, Yogyakarta, Indonesia; \\ ${ }^{2}$ Indonesia Agricultural Engineering Polytechnic (IAEP), Serpong, Indonesia; ${ }^{3}$ Department of Agricultural \\ Socio Economics, Faculty of Agriculture, Universitas Gadjah Mada, Yogyakarta, Indonesia
}

*Corresponding author: temy_22@yahoo.com

\begin{abstract}
Several kinds of agro-tourism are managed by the community and by the private sector. However, if agro-tourism is managed by the community, can it give satisfaction to the visitors? This study aims to determine the level of customer satisfaction by Customer Satisfaction Index (CSI) and to investigate what marketing mix attributes should be improved by IPA-Kano integration analysis. The research method used was a quantitative research on community-based Salak (Salacca zalacca) Agro-tourism in each category of tourism village, namely 'growing', 'developing' and 'independent' tourism village categories. The measurement of visitor satisfaction used the marketing mix attributes of 7Ps (price, place, product, promotion, process, people and physical evidence). Based on the results of CSI, the services provided by the community-based salak agro-tourism manager are considered 'Satisfied' in the Growing and Developing agro-tourisms and 'Very Satisfied' in the Independent agro-tourism. Priority attributes that should be improved are attributes included in the 'Fatal' category. Priority attributes in 'growing' agro-tourism are the marketing activities (publicity), availability and cleanliness toilet. Priority attributes in 'developing' agro-tourism are marketing activities (promotion), availability and cleanliness of toilets. Priority attributes in 'independent' agro-tourism are availability and cleanliness of toilets.
\end{abstract}

Keywords: agro-tourism development; consumer satisfaction; IPA-kano integration; marketing mix

Cite this as: Indrayanti, T., Jamhari, Mulyo, J. H., \& Masyhuri. (2020). The Customer Satisfaction Analysis of Community based Agrotourism in Yogyakarta. Caraka Tani: Journal of Sustainable Agriculture, 35(1), 33-43. doi: http://dx.doi.org/10.20961/carakatani.v35i1.29336

\section{INTRODUCTION}

Tourism is an industry that is widely developed by either developed or developing countries to increase state revenue in the form of foreign exchange. The tourism industry is widely developed in many countries for some reasons. They are: 1) traveling has become human basic need, 2) tourism is considered as a low-waste and relatively clean industry if compared to other industries, 3) tourism gives a positive impact on the expansion of employment opportunities in business so that it can increase the community income and 4) tourism is a place for socio-cultural interaction, at both national and international levels (Yoeti, 2008).

One of the tourism sectors in Indonesia that has a potency for development is agro-tourism. It offers visitors an opportunity to experience rural lifestyle, allow them to be in a close contact with nature and to be involved directly in agricultural activities such as animal feeding, pick-your-own, participation in manufacturing process, etc. (Ezung, 2012). Sznajder et al. (2009) emphasizes that agro-tourism provides an opportunity to the tourists to be involved in a recreational activity in the rural area to extend their knowledge, as well as to get a recreational experience and a business

\footnotetext{
* Received for publication April 16, 2019

Accepted after corrections October 26, 2019
} 
relationship in the agricultural sector. Past studies have shown that agro-tourism is an efficient economic driver against rural underdevelopment and depopulation, which is used as an important element of regional development strategy (Niedziółka and Brzozowska, 2009; Malkanthi and Routry, 2011; Hurst and Niehm, 2012).

In the real practices, the development of agrotourism cannot be separated from the community around the agro-tourism area. Local communities play a key role in the success of an agro-tourism. An effort to involve the community in developing agro-tourism takes form an idea to develop procommunity tourism, known as Community-Based Tourism (CBT). CBT can be identified as a community development strategy through selfreliance, empowerment, sustainability, conservation and cultural development to improve livelihoods in the community (Diharto et al., 2018). Society occupies a position as an integral part that participate as both subject and object. Community participation is the main instrument due to the capacity for reinforcing the development of tourism businesses, particularly agro-tourism.

Salak (Salacca zalacca) agro-tourism managers have recognized that they have to compete with similar businesses, and thus, they need to improve their services. Agro-tourism development is related to the presence of visitors. Marketing plays a role in attracting and increasing the number of visitors. Market research and understanding of visitor expectations when visiting a CBT are highly significant in enhancing the success of CBT development (Mtapuri et al., 2015). Kayat (2014) argued that efficient marketing is compulsory to raise awareness about their offerings and inform potential visitors as they choose destinations, as well as ensure sustainability.

To reach the planned visiting level, a manager develop a marketing mix strategy. The marketing mix is a combination of a number of controlled marketing variables and is used by the business as a tool to achieve the targets set by the business. According to (Wilson et al., 2009), marketing generally has a role in providing value to customers. The basic dimensions of providing value are defined in terms of the "Four Ps" framework, namely, product, promotion, price and placement (Perrault and McCarthy, 2002). Field conditions continue to grow and the marketing mix is expanded to be more effective in accordance with the condition in which the company operates. The culmination of this effort couples with the movement towards a serviceoriented economy, resulting in a marketing mix consisting of three unique dimensions which broaden the four Ps, namely the dimensions of physical evidence, people and processes. Salak Agro-tourism marketing strategy emphasizes seven marketing variables, commonly known as 7Ps, including product, place, price, promotion, people, physical evidence, process.

Customer satisfaction is an essential parameter of sustainable business. The increasingly aggressive competition has demanded a service provider to always pamper consumers by providing the best service. Service quality is an important component in consumer perception and in its influence on customer satisfaction. The better the quality of services provided is, the better the image of customers will be. Ooi et al. (2011) defined customer satisfaction as the level of one's feelings as a result of a comparison between reality and expectations received from a product or service. When product performance is lower than the expectations of customers, buyers are not satisfied. If performance matches expectations or exceeds expectations, buyers feel satisfied or feel highly contented. Satisfied customers will repurchase and tell others about good experiences about the product. The key is to integrate customer expectations with company performance. Smart companies have the goal of making customers happy by promising only what they can give, then giving more than they promise. Therefore, the purpose of this study was to determine the level of satisfaction of visitors of community-based salak agro-tourism in the Special Region of Yogyakarta and to identify the attributes that must be improved to upsurge customer satisfaction.

\section{MATERIALS AND METHOD}

Research on the satisfaction of visitors in community-based salak agro-tourism was carried out in Turi Sub-district, Sleman Regency, Yogyakarta, the center of development for the salak commodity. The research was conducted from November 2017 to April 2018. This study uses a quantitative research.

The business sampling method was done with purposive sampling, a deliberate sampling technique based on certain criteria or consi- 
derations. The sample taken in this study was community-based salak agro-tourism and represented each category of tourism villages; they are Pulesari Tourism Village representing 'independent' agro-tourism, Pancoh Tourism Village representing 'developing' agro-tourism, and Ledok Nongko Tourism Village representing 'growing' agro-tourism. The Sleman Regency Tourism Office (2016) divided CBT (tourism village) into three categories, namely the 'growing', 'developing' and 'independent'. The visitor sample taking was performed with purposive sampling technique. Respondents who chosen the salak agro-tourism tour package in addition to other tour packages. There were 30 visitors in each designated salak agro-tourism.

Data were collected through a questionnaire by providing a list of questions to tourists visiting salak agro-tourism as respondents and a five point Likert scale, embedded in a structured questionnaire, to explore the level of importance and the level of performance, and function and dysfunction services.

The analytical tool used to determine the level of customer satisfaction was the ImportancePerformance Analysis (IPA) by calculating the Customer Satisfaction Index (CSI). The first step to measure CSI was the determination of the Mean Importance Score (MIS) and Mean Satisfaction Score (MSS). This value comes from the average level of importance and performance of each attribute, with the formula:

$$
\begin{aligned}
M I S & =\frac{\sum_{i=l}^{n} Y i}{n} \\
M S S & =\frac{\sum_{i=l}^{n} X i}{n}
\end{aligned}
$$

Here, $\mathrm{n}$ is the number of respondent, $\mathrm{Yi}$ is importance value of attribute at- $\mathrm{i}$ and $\mathrm{Xi}$ is performance value of attribute at-i. The second step was the calculation of the Weight Factors (WF) that is the percentage of MIS values per attribute against the total MIS of all attributes.

$$
W F i=\frac{M I S i}{\sum_{i=l}^{p} M I S i} \times 100 \%
$$

Here, $p$ is the number of attributes of interest and $i$ is attribute at-i. The third step was the calculation of the Weight Score (WS) that is the multiplication of WF with the average level of satisfaction (MSS).

$$
W S i=W F i \times M S S i
$$

The last step was the calculation of CSI with the formula:

$$
C S I=\frac{\sum_{i-l}^{p} W S i}{5} \times 100 \%
$$

The overall level of satisfaction of respondents can be seen from the visitor satisfaction criteria listed in Table 1.

Table 1. Visitor satisfaction criteria

\begin{tabular}{cc}
\hline CSI value & CSI criteria \\
\hline $81-100$ & Very satisfied \\
$66-80$ & Satisfied \\
$51-65$ & Satisfied enough \\
$35-50$ & Less satisfied \\
$0-34$ & Dissatisfied \\
\hline
\end{tabular}

Source: (Chandrawatisma and Sukardi, 2006)

Service attributes that must be improved to increase customer satisfaction can be determined using the IPA-Kano Integration Analysis. The IPA-Kano Integration Analysis is an analysis that combines the results of the IPA analysis and the results of Kano analysis, which can later determine the service attributes included in the priority of improvement. The first step is to identify service attributes with IPA by analyzing and classifying attributes into "Concentrate Here", "Keep up the Good Work", "Low Priority" and "Possible Overkill" (Figure 1).

The next step is the identification of attributes with the Kano Model by classifying attributes into Kano categories namely Questionable (Q), Reverse (R), Attractive (A), Indifferent (I), One dimensional (O) and Must be (M). The ' $\mathrm{M}$ ' occurs if the customer feels dissatisfied when the performance of product attributes (goods or services) is low, but customer satisfaction does not increase beyond the neutral area even though the performance of product attributes is high. The ' $\mathrm{O}$ ' occurs if customer satisfaction has a linear function with the performance of product attributes. High product attribute performance also results in high customer satisfaction. The ' $\mathrm{A}$ ' occurs if customer satisfaction increases multiple times as attribute performance increases, but the 
decrease in performance of this attribute does not cause a decrease in the level of customer satisfaction. The 'I' occurs if the presence or absence of attributes in this category does not affect the service user satisfaction. The ' $Q$ ' occurs if service users feel satisfied or dissatisfied with the existence of attributes in this category, so there is no clarity whether the attributes in this category are expected or not. The ' $R$ ' occurs if service users are satisfied if the attributes in this category do not exist or in other words service users do not feel satisfied if there are attributes in this category (Kano et al., 1984).

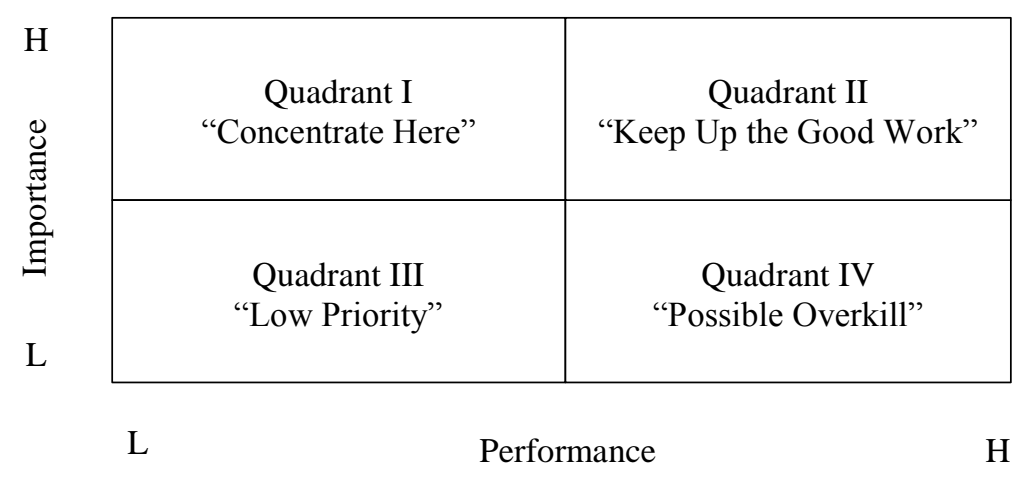

Figure 1. Quadrant of IPA (Martilla and James, 1977)

After the analysis of IPA and Kano model, the attributes that are included in the priority of improvement can be determined with several indicators (Kuo et al., 2012).

1. These attributes are attributes that include IPA I quadrant. The reason for choosing quadrant $I$ is that it has a large level of importance but service user satisfaction is still lacking.

2. The Kano category that is chosen for improvement is in accordance with the rules $\mathrm{M}>\mathrm{O}>\mathrm{A}>\mathrm{I}$ (Figure 2).

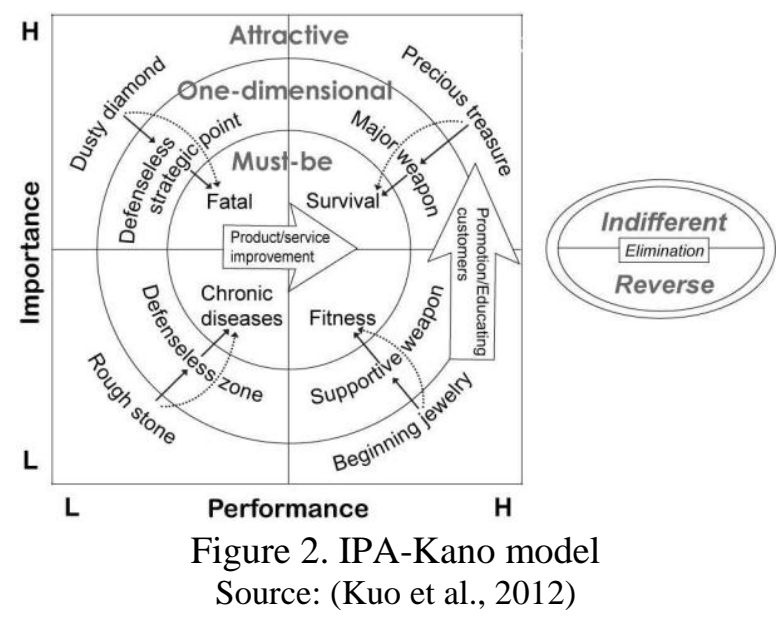

\section{RESULTS AND DISCUSSION}

Consumer satisfaction can only be achieved by providing good quality services to consumers.
Good services are often valued by consumers directly. Therefore, an effort is needed to improve the quality of services provided in order to fulfill the desires and increase the customer satisfaction. Thus, service quality is an important aspect that must be considered by the company in order to achieve customer satisfaction. The level of customer satisfaction of community-based salak agro-tourism in each tourist village category can be seen in Table 2. The results of the IPA-Kano Analysis are presented in Table 3.

Table 2. Community-based salak agro-tourism customer satisfaction at each category of tourism village

\begin{tabular}{clcl}
\hline No. & Agro-tourism & CSI & \multicolumn{1}{c}{ Score } \\
\hline 1. & Growing & 73.14 & Satisfied \\
2. & Developing & 73.51 & Satisfied \\
3. & Independent & 84.00 & Very satisfied \\
\hline
\end{tabular}

\section{'Growing' agro-tourism}

Ledok Nongko Tourism Village is a tourist village that is included in the 'Growing' category. The attractions offered in this tourist village only specialize in educational and training activities in organic salak cultivation for students, university students and the common people from society. Other tourism activities have not yet been developed. Salak in Ledok Nongko Tourism Village is organic and certified in quality (Organic Persada and IMO International Organic). 
Table 3. Service attributes included in priority improvement based on IPA-Kano integration analysis

\begin{tabular}{|c|c|c|}
\hline Agro-tourism & Service attribute category & Service attribute \\
\hline \multirow{3}{*}{$\begin{array}{l}\text { Growing } \\
\text { (Ledok Nongko } \\
\text { Tourism Village) }\end{array}$} & $\begin{array}{l}\text { Fatal } \\
\text { (quadrant I-must be) }\end{array}$ & $\begin{array}{l}\text { - Publicity } \\
\text { - Toilet }\end{array}$ \\
\hline & $\begin{array}{l}\text { Defenseless strategic point } \\
\text { (quadrant I - one dimensional) }\end{array}$ & $\begin{array}{l}\text { - Variation of tourist attraction } \\
\text { - Quality of tourist attractions } \\
\text { - Means of transportation } \\
\text { - Infrastructure } \\
\text { - Accommodation facilities } \\
\text { - Restaurant } \\
\text { - Garbage bin } \\
\text { - Meeting room } \\
\text { - Responses to criticism and suggestions } \\
\text { - Shop of product sales }\end{array}$ \\
\hline & $\begin{array}{l}\text { Dusty diamond } \\
\text { (quadrant I - attractive) }\end{array}$ & $\begin{array}{l}\text { - Tourist attraction innovation } \\
\text { - Advertising } \\
\text { - Promotion } \\
\text { - Number of employee } \\
\text { - Layout and design }\end{array}$ \\
\hline \multirow{2}{*}{$\begin{array}{l}\text { Developing } \\
\text { (Pancoh Tourism } \\
\text { Village) }\end{array}$} & $\begin{array}{l}\text { Fatal } \\
\text { (quadrant I- must be) }\end{array}$ & $\begin{array}{l}\text { - Promotion } \\
\text { - Toilet }\end{array}$ \\
\hline & $\begin{array}{l}\text { Defenseless strategic point } \\
\text { (quadrant I - one dimensional) }\end{array}$ & $\begin{array}{l}\text { - Variation of tourist attraction } \\
\text { - Tourist attraction innovation } \\
\text { - Means of transportation } \\
\text { - Accommodation facilities } \\
\text { - Meeting room } \\
\text { - Shop of product sales }\end{array}$ \\
\hline \multirow{2}{*}{$\begin{array}{l}\text { Independent } \\
\text { (Pulesari Tourism } \\
\text { Village) }\end{array}$} & $\begin{array}{l}\text { Fatal } \\
\text { (quadrant I- must be) }\end{array}$ & - Toilet \\
\hline & $\begin{array}{l}\text { Defenseless strategic point } \\
\text { (quadrant I - one dimensional) }\end{array}$ & $\begin{array}{l}\text { - Means of transportation } \\
\text { - Accommodation facilities } \\
\text { - Shop of product sales }\end{array}$ \\
\hline
\end{tabular}

The result of CSI measurements in Ledok Nongko Tourism Village is 73.14 which means that consumers (visitors) felt satisfied with the services provided by the management of Ledok Nongko Tourism Village. However, based on the results of the IPA-Kano Integration analysis, there are attributes of service that fell into 'Fatal' category and must be improved by the management of Ledok Nongko Tourism Village because it would cause high dissatisfaction to the users of the service. The attributes are marketing activities (publicity), toilet availability and cleanliness. Ledok Nongko Tourism Village has not optimally conducted marketing activities. This is due to limited human resources, in which most of them are at old age, so they only rely on relations from local travel agents. The majority of young people (productive) work outside the village. Maneenetr et al. (2014) said that to promote local community participation in the development of agro-tourism, several strategies have to be made: 1) promoting agro-tourism through advertising 2) improving local facilities to respond tourists' needs and expectation, 3) establishing a local agricultural learning center 4) building agro-tourism networks and 5) promoting the roles of the young members of the community in agro-tourism. Moreover, the tourist village does not have public toilets, so the visitors must use villagers' toilets.

Ledok Nongko Tourism Village must also improve service attributes that are in the Defenseless Strategic Point category, which can increase visitor satisfaction, including variations in tourist attractions, quality of tourist attractions, means of transportation, infrastructure, accommo- 
dation facilities, restaurants, garbage bin, meeting rooms, responses to criticism and suggestions and product sales shops. This village does not have a variety of tourist attractions offered to visitors. The manager only offers an organic salak education package and salak fruit harvesting. There are no other tourist attractions like those offered by other tourism villages. This is due to limited space for additional attractions and this can happen because there is no space or land in the village that is donated for facility and activity, for example, the absence of rivers for river flow activities, the absence of open fields for outbound activities or areas for meetings, product sales shops and art shows. This resulted in the condition that the majority of visitors can only feel the sensation of harvesting and enjoy organic salak fruit directly with little point of education from the manager regarding their cultivation. Visitors cannot linger in the tourist village for a longer duration. The availability of homestays in the tourist area in common is only used for students who are in Field Work Practice. Tourist visitors rarely use the facility because of the limited tourist attractions offered.

Therefore, it is necessary to provide facilities that make visitors feel at home or comfortable to stay longer such as lodging facilities (accommodation) and providing more attractive tour packages. The provision of a salak education tour package does not only provide education for organic salak cultivation but also can educate various processed foods or snacks from salak. This facility supports the achievement of increasing the added value of agro-tourism products perceived by consumers. It also focuses on the quality of agricultural product and places consideration on providing healthful food for consumers (Hjelmar, 2011). Transferring to organic agriculture increases the income of the local community and creates image of an organic agriculture destination for tourists. At present, many tourists visit village to experience the fresh atmosphere of the destination and learn about organic farm processes. This enables the local community to gain additional income from agrotourism activities (Maneenetr et al., 2014).

The manager of Ledok Nongko Tourism Village has also not provided an optimal response to criticisms and suggestions from visitors because the manager feels and admits the limitations they have. This has led to the passive existence of the Ledok Nongko Tourism Village, which has even decreased the quality of tourism. Umar (2003) stated that managers must have the ability to communicate to convey information to customers or obtain input from customers and understand customers about their needs and desires. Lin et al. (2018) also stated that tourists' perceptions of service quality are significantly influenced by professional competence (professional attitude, professional knowledge and professional skills) of tour guides. A positive professional attitude can bridge the gap between tourists, tour guides and tourism managers. In addition, employee service can influence consumer satisfaction that comes from shopping experience (Lovelock and Wirtz, 2011). Engeset and Heggem (2015) also states that an important strategy in agro-tourism product development is personal contact with consumers. Managers can confirm orders by contacting guests for a second time, either by email or by call. Thus, the manager can find out the shortcomings of the business being run, so that it can improve the quality of service.

Improvements in service attributes included in the Dusty Diamond category also need to be carried out by the management of Ledok Nongko Tourism Village. There are tourist attraction innovations, advertising, promotions, increasing number of employees and design and layout of locations. Fixed attributes can attract the attention of visitors to come in the Ledok Nongko Tourism Village. The tourist attraction innovation needs to be provided by the manager to improve variety of attractions offered, so that visitors do not only learn about the cultivation of salak fruit, but they can also enjoy the other tourist attractions offered, for example, arts events or local customs. Wang et al. (2012) revealed other major factors effecting tourist experience; they are resource conditions, recreational activities, tourism facilities, integrated management, related personnel and the quality of service that is considered a main determinant factor of customers' experience. Tung and Ritchie (2011) emphasize the necessity of several conditions required for the process of creating memorable tourist experiences. The first important thing is qualified human resources, in particular skilled tour guides; second, stimulating interaction between tourists and the local community; and, last, the creation of a surprising element as a driver of high levels of customer satisfaction. 


\section{'Developing' agro-tourism}

Pancoh tourist village is a tourist village that is included in the developing category. The number of visitors in the Pancoh Tourism Village is increasing from year to year. The tourism organizations are capable of serving the number of tourists by increasing the supporting facilities and other tourist facilities. The facilities that are already complete include homestay (with bathroom facilities, clean water and electricity), public toilets already available at camping and "joglo" locations, stage shows and supporting tools for artistic activities. Pancoh Tourism Village has the potential of a tourist attraction with the concept of ecotourism. There are rivers, ponds, organic farming, livestock raising and biogas processing and salak plantations. The attractions offered include river tracking, outbound, picking of salak and organic vegetables and art activities ("Wiwit", "Nyadran", "Njenangi" and "Mitoni")

The result of CSI measurements in Pancoh Tourism Village was 73.51, which means that visitors felt satisfied with the services provided by the manager of the Pancoh Tourism Village. Based on the results of the analysis of the Integration of IPA-Kano, there are still service attributes included in the Fatal category and must be improved by the manager of the Pancoh Tourism Village, which are marketing activities (promotion), availability and cleanliness of toilets. The management still needs to do more intensive marketing activities to attract visitors, not only in the region of Yogyakarta but also out of the region of Yogyakarta. Pancoh Tourism Village can carry out promotional activities through electronic mass media such as on local television stations in the city of Yogyakarta and its surroundings. Television has become one of the most popular media among the public. Television has the advantage of being very effective (powerful) in conveying information visually to the public. According to data from the 2015 Central Statistics Agency, 91.47 percent of the population over the age of 10 still uses television as the main access to information.

The thing that is often complained about by visitor every time they come to the Pancoh Tourism Village is the availability and cleanliness of the toilet. This is because the average visitors in Pancoh Tourism Village come from big cities and they want to enjoy the rural atmosphere. The level of cleanliness of the people of the city and the village community is different. The toilets available in the tourism village do not meet the standards of visitors from cities.

Service attributes that are in the Defenseless Strategic Point category that must be repaired by the manager of the Pancoh Tourism Village are the variations and innovations of attractions offered, accommodation facilities, meeting rooms, transportation equipment and product sales shop. The facilities are available in the tourist area, but they are simple and limited, and therefore, they need improvement to help increase visitor satisfaction. The Pancoh Tourism Village does not have a permanent area of product sales shop. Availability of product sales shop is necessary to sell the typical products and souvenirs of the tourist village community that visitors can purchase. Umar (2003) revealed that if the facilities needed by consumers in tourist attractions are available, the level of customer satisfaction would increase.

\section{'Independent' agro-tourism}

Pulesari Tourism Village is a tourist village that is included in the Independent category since its inception in 2012. Pulesari village has a high level of development, especially seen from the high number of visitors. The service facilities, tourist attractions and human resources can serve tourists in large numbers. The tourist village has a good managerial organization. Most people are involved in every tourism activity. The attractions offered by Pulesari Tourism Village are salak tourism, Outbound and River Tracking, Art ("Salak" Dance, "Kubro Siswo", "Bergodo", "Kleting Sari", "Hadroh", "Jathilan", "Dayakan"), Processed food ("Dodol Salak", "Geplak Salak", "Enting-enting Salak", "Jenang Salak", "Wingko Salak", "Wajik Salak", "Bakpia Salak").

The result of CSI measurement in Pulesari Tourism Village was 84.00 , which mean that visitors felt very satisfied with the services provided by Pulesari Tourism Village managers. Pulesari Tourism Village is one of the tourism villages that has been independent in its management and the Sleman Regency government prepares Pulesari Tourism Village as a competitive tourism village. The managers are able to serve visitors in large numbers every day and provide good services supported by sufficient facilities. However, based on the analysis of the Integration of IPA-Kano, there are still a number 
of aspects that must be improved by the management included in the fatal category, which are the availability and cleanliness of toilet. The availability and cleanliness of the toilets have not met the standard conditions of the visitors' needs, which on average come from urban areas, so there are still complaints from visitors regarding the availability of toilets.

Other service attributes in the Defenseless Strategic Point category that must be improved are the accommodation facilities, product sales shops and means of transportation. If these three attributes can be managed properly by the manager, visitor satisfaction and the level of visitor can be enhanced.

Satisfaction can be measured from tourists' expectations as well as their actual formation of positive feeling to reach tourist destinations during or after the process of tourism consumption (del Bosque and Martín, 2008). AlAbabneh (2013) said that service quality directly impacted tourist satisfaction throughout destination facilities, destination accessibility and destination attraction. Sugandini et al. (2017) stated that community that can satisfy the tourists have an impact on the willingness of tourists to visit tourist destination and improve word of mouth communication (Dyah et al., 2017; Haryono et al., 2017). However, increasing customer satisfaction by enhancing the tourist experience requires a better understanding of customer needs and their individual preferences (Hurst and Niehm, 2012).

Based on CSI analysis, each agro-tourism has given satisfaction to consumers. However, most visitors cannot be dependable on this agrotourism. They only come once to enjoy the provided agro-tourism service. In the research by Sugandini et al. (2018), the primary data analysis shows that tourism destination quality, satisfaction, and image according to the visitor perception are good, but these are not in line with the visitors' level of loyalty. Most of the tourists visit Special Region of Yogyakarta just once and they merely consider this area as a transit destination.

In general, community-based salak agro tourism in Sleman Regency (Ledok Nongko Tourism Village, Pancoh Tourism Village, Pulesari Tourism Village and other tourist villages) encounter the identical problems, namely accommodation facilities that have not met the standards of visitor needs, availability of toilets that has not reached to the level of cleanliness of the urban community and the limited availability of public transportation to the location of tourist villages.

Complaints about the availability of homestays and toilets are often made by visitors coming from big cities outside Yogyakarta because of the different standard of living between rural communities in Yogyakarta and other big city communities. Choo et al. (2017) said in their research that the factors of price and cleanliness are the most salient for rural accommodation selection criteria. In addition, the unavailability of public transportation to the location of tourist villages makes it difficult for visitors who want to come individually or in small groups. During this time, the village tourism manager cooperates with travel agents with their fleets to bring visitors to the tourist village location. Bagi and Reeder (2012) said that public access to the farm for recreation has the greatest positive impact, followed by farms near central cities. Therefore, there is a need for partnerships that can help in overcoming these problems by the collaboration between village tourism and travel agents so it is expected to ease visitors who plan to come to the tourist village. According to Budiasa and Ambarawati (2014), The conditions might be due to limited capacity of local community in agro-tourism, inadequate budget to provide many standardized agro-tourism facilities, lack of adequate promotion, and limited agro-tourism landscaping.

The existence of agro-tourism is expected to give enhanced contribution to the future of Indonesian regional tourisms in general. To advance agro-tourism development and contribution to sustainable, appropriate capacity building programs on agro-tourism for local community, supported by government budget and/or corporate social responsibility programs, will be helpful and useful (Budiasa and Ambarawati, 2014). Jensen et al. (2014) add that agro-tourism can serve as a means for farmers to diversify their operations to add to farm income, even on small farms. These farmers are moving towards alternative forms of economic activities such as organic farming and provision of farm house accommodation (Flanigan et al., 2014; Olya et al., 2014). Hamilpurka (2012) indicated that agro-tourism in Karnataka in India, has improved farmers' income and contributed to educating the tourists and local communities on sustainable agriculture. Finally, human resources as a major 
asset in an organization also need to be upgraded since capabilities, skills and knowledge of tourism service providers have significant roles in the success of agro-tourism (Handriana and Ambara, 2016).

\section{CONCLUSIONS}

Based on the calculation of the CSI, the services provided by the community-based salak agro-tourism manager are considered Satisfied in the 'Growing' and 'Developing' agro-tourism category and considered Very Satisfied in the 'Independent' Tourism Village category. Priority attributes that should be improved are attributes included in the 'Fatal' category. Priority attributes in 'growing' agro-tourism are the marketing activities (publicity), availability and cleanliness toilet. Priority attributes in 'developing' agrotourism are marketing activities (promotion), availability and cleanliness of toilets. Priority attributes in 'independent' agro-tourism are availability and cleanliness of toilets.

\section{REFERENCES}

Al-Ababneh, M. (2013). Service Quality and its Impact on Tourist Satisfaction. Inter disciplinary Journal of Contemporary Research in Business, 4(12), 164-177. Retrieved from https://journal-archieves31. webs.com/164-177.pdf

Bagi, F. S., \& Reeder, R. J. (2012). Factors affecting farmer participation in agritourism. Agricultural and Resource Economics Review, 4l(2), 189-199. https://doi.org/10.1017/S106 8280500003348

Budiasa, I. W., \& Ambarawati, I. G. A. A. (2014). Community based agro-tourism as an innovative integrated farming system development model towards sustainable agriculture and tourism in Bali. Journal of the International Society for Southeast Asian Agricultural Sciences, 20(1), 29-40. Retrieved from https://simdos.unud.ac.id/uploads/file_p enelitian_1_dir/f779a3dfe8d559a3f670a0059 27cb58a.pdf

Chandrawatisma, C., \& Sukardi. (2006). Analisis Tingkat Kepuasan Pelanggan terhadap Produk Corned Pronas Produksi PT CIP, Denpasar Bali. Jurnal Teknologi Industri Pertanian, 18(2), 106-117. Retrieved from https:// repository.ipb.ac.id/handle/123456789/40462

Choo, S., Lee, K., \& Park, J. (2017). Development of rural accommodation selection criteria: The case of South Korea. European Journal of Tourism Research, 17, 246-260. Retrieved from http://ejtr.vumk.eu/index.php/volume17 /509-v17246

del Bosque, I. R., \& San Martín, H. (2008). Tourist satisfaction a cognitive-affective model. Annals of Tourism Research, 35(2), 551-573. https://doi.org/10.1016/j.annals.200 8.02 .006

Diharto, A. K., Ismail, Y., Iriantini, D. B., Murtadlo, M. B., \& Muafi. (2018). The role of community based tourism based on local wisdom using online media. International Journal of Civil Engineering and Technology, 9(2), 908-915. Retrieved from https://www. iaeme.com/MasterAdmin/uploadfolder/IJCIE T_09_02_087/IJCIET_09_02_087.pdf

Dyah, Y. S., Istiana, R., \& Istanto. (2017). Adoption of Natural Dyes for Batik Artisans in Yogyakarta, Indonesia. Review of Integrative Business and Economics Research, 6(1), 349359. Retrieved from http://eprints.upnyk.ac. id/11438/

Engeset, A. B., \& Heggem, R. (2015). Strategies in Norwegian Farm Tourism: Product Development, Challenges, and Solutions. Scandinavian Journal of Hospitality and Tourism, 15(1-2), 122-137. https://doi.org/10. 1080/15022250.2015.1005332

Ezung, Z. T. (2012). Rural Tourism in Nagaland, India: Exploring the Potential. International Journal of Rural Management, 7(1-2), 133147. https://doi.org/10.1177/09730052124598 33

Flanigan, S., Blackstock, K., \& Hunter, C. (2014). Agritourism from the perspective of providers and visitors: A typology-based study. Tourism Management, 40, 394-405. https://doi.org/ 10.1016/j.tourman.2013.07.004

Hamilpurka, S. (2012). Agri-Tourism In Karnataka - Issues, Constraints And Possibilities. International Journal of Research In Commerce, Economics \& Management, 2(7), 106-111. Retrieved from https://ijrcm.org.in/article_info.php?article_id $=1974$ 
Handriana, T., \& Ambara, R. (2016). Responsible environmental behavior intention of travelers on ecotourism sites. Tourism and Hospitality Management, 22(2), 135-150. https://doi.org/ 10.20867/thm.22.2.4

Haryono, S., Kustyadji, G., El Qadri, Z. M., \& Muafi. (2017). Analysis of Domestic Turist Market. Journal of Environmental Mana gement and Tourism, 8(24), 1591-1598. Retrieved from https://journals.aserspublishi ng.eu/jemt/article/view/1896

Hjelmar, U. (2011). Consumers' purchase of organic food products. A matter of convenience and reflexive practices. Appetitie, 56(2), 336-344. http://dx.doi.org/10.1016/j. appet.2010.12.019

Hurst, J. L., \& Niehm, L. S. (2012). Tourism shopping in rural markets: A case study in rural Iowa. International Journal of Culture, Tourism and Hospitality Research, 6(3), 194208. https://doi.org/10.1108/17506181211246 357

Jensen, K. L., Bruch, M., Menard, R. J., \& English, B. C. (2014). Analysis of Factors Influencing Businesses in Expansion. Journal of Food Distribution Research, 45(2), 118134. http://dx.doi.org/10.22004/ag.econ.1869 28

Kano, N., Seraku, N., Takahashi, F., \& Tsuji, S. (1984). Attractive Quality and Must Be Quality. Journal of The Japanese Society for Quality Control, 14(2), 147-156. https://doi. org/10.20684/quality.14.2_147

Kayat, K. (2014). Community-Based Rural Tourism: A Proposed Sustainability Framework. SHS Web of Conferences, 12, 01010. https://doi.org/10.1051/shsconf/20141 201010

Kuo, Y. F., Chen, J. Y., \& Deng, W. J. (2012). IPA-Kano model: A new tool for categorising and diagnosing service quality attributes. Total Quality Management and Business Excellence, 23(7-8), 731-748. https://doi.org/10.1080/147 83363.2011 .637811

Lin, Y. C., Lin, M. L., \& Chen, Y. C. (2018). Examining the Impacts of Tour Guides' Professional Competences on Service Quality, Tourist Satisfaction and Repurchase Intentions towards Package Tour Products. Journal of
Tourism and Hospitality Management, 6(2), 26-38. https://doi.org/10.15640/jthm.v6n2a9

Lovelock, C., \& Wirtz, J. (2011). Services Marketing: People, Technology, Strategy (7th ed.). Boston: PrenticeHall. Retrieved frim https://www.researchgate.net/publication/263 523474_Services_Marketing_People_Technol ogy_Strategy_7th_edition

Malkanthi, S. H. P., \& Routry, J. K. (2011). Potential for agritourism development: evidence from Sri Lanka. The Journal of Agricultural Sciences, 6(1), 45-58. http://dx. doi.org/10.4038/jas.v6i1.3812

Maneenetr, T., Naipinit, A., \& Tran, T. H. (2014). Guidelines to promote local community participation in developing agrotourism: A case study of Ban Mor Village, Sam Sung District, Khon Kaen Province, Thailand. Asian Social Science, 10(9), 178-186. https://doi. org/10.5539/ass.v10n9p178

Martilla, J. A., \& James, J. C. (1977). ImportancePerformance Analysis. Journal of Marketing, 41(1), 77-79. https://doi.org/10.2307/1250495

Mtapuri, O. (2015). Community-based tourism affinity index: a visitor's approach. African Journal of Hospitality, Tourism and Leisure, 4(2), 1-13. Retrieved from https://www. researchgate.net/publication/279952366_Com munity-based_tourism_affinity_index_a_visi tor's_approach

Niedziółka, A., \& Brzozowska, A. (2009). Aspects of Agritourism Management in Malopolska Voivodeship. Annals of the University of Petroşani, Economics, 9(4), 105-112. Retrieved from https://EconPapers. repec.org/RePEc:pet:annals:v:9:i:4:y:2009:p: $105-112$

Olya, G., Alipour, H., \& Dalir, S. (2014). An Entrepreneurial Tourism Project through Agro-Tourism Farm in Iran. Journal of Sustainable Development Studies, 6(1), 48-63. Retrieved from https://ideas.repec.org/a/pet /annals/v9i4y2009p105-112.html

Ooi, K. B., Lin, B., Tan, B. I., \& Chong, A. Y. L. (2011). Are TQM practices supporting customer satisfaction and service quality? Journal of Services Marketing, 25(6), 410419. https://doi.org/10.1108/08876041111161 005 
Perrault, W. D., \& McCarthy, E. J. (2002). Basic Marketing: A Global Managerial Approach. New York: McGraw-Hill Publishing Co. Retrieved from https://www.academia.edu/26 708903/Basic_Marketing-Global_Managerial _Approach

Sugandini, D., Effendi, M. I., Aribowo, A. S., \& Utami, Y. S. (2018). Marketing Strategy on Community Based Tourism in Special Region of Yogyakarta. Journal of Environmental Management and Tourism, 9(4), 733-743. https://doi.org/10.14505//jemt.v9.4(28).06

Sugandini, D., Wendry, B., \& Muafi. (2017). Influence of quality relationship and satisfaction on loyalty: study on supplier in Indonesia. Journal of Business \& Retail Management Research, 11(4), 46-51. https:// doi.org/10.24052/jbrmr/v11 is04/ioqrasolsosii

Sznajder, M., Przezbórska, L., \& Scrimgeour, F. (2009). Agritourism. Wallingford [etc.]: CABI Publishing. http://dx.doi.org/10.1079/9781845 934828.0000
Tung, V. W. S., \& Ritchie, J. R. B. (2011). Exploring the essence of memorable tourism experiences. Annals of Tourism Research, 38(4), 1367-1386. https://doi.org/10.1016/j. annals.2011.03.009

Umar, H. (2003). Riset Pemasaran dan Perilaku Konsumen. Jakarta: PT Gramedia Pustaka Utama.

Wang, W., Chen, J. S., Fan, L., \& Lu, J. (2012). Tourist experience and Wetland parks: A case of Zhejiang, China. Annals of Tourism Research, 39(4), 1763-1778. https://doi.org/ 10.1016/j.annals.2012.05.029

Wilson, A., Zeithaml, V. A., Bitner, M. J., \& Gremler, D. D. (2009). Services Marketing: Integrating Customer Focus Across The Firm. (5th ed.). Singapore: McGraw-Hill and Irwin. Retrieved from https://www.academia.edu/14 707918/Services_Marketing_Integrating_Cust omer_Focus

Yoeti, O. A. (2008). Ekonomi Pariwisata. Jakarta: PT. Kompas Media Utama. 